\title{
HYBRID WAR AND ITS IMPACT \\ ON ECONOMIC SECURITY GOVERNMENT
}

\section{ГІБРИДНА ВІЙНА ТА ЇЇ ВПЛИВ \\ НА ДЕРЖАВНЕ УПРАВЛІННЯ ЕКОНОМІЧНОЮ БЕЗПЕКОЮ}

\section{Hbur Zoriana ${ }^{1}$}

DOI: http://dx.doi.org/10.30525/978-9934-571-26-8_5

Abstract. The article defines the difference between traditional and nontraditional warfare. The essence of the concept of "hybrid war", as one of the types of informal and / or non-traditional warfare from the standpoint of various scholars, politicians and other statesmen, is described. As a result, the actual definition is proposed: a hybrid war - a set of tools and tools used by the enemy, which includes not only and not only nuclear, biological, chemical weapons, but a complex of information, high-tech, cybernetic means of influence, psychological pressure to achieve political goals. The basic forms of the hybrid war have been found out. The classification of types of weapons used in hybrid warfare is described, as well as its influence on modern processes of European integration is clarified.

A number of scholars and political figures paid attention to this issue, among them: R. Arzumanyan [1], O. Vasilenko [2], O. Galak [3], V. Horbulin [4; 5], A. Demidov [6], E. Magda [7], Malsky [8], V. Pobordsky [9], L. Savin [10] and others.

The purpose of this article is to reveal the essence of the hybrid war and determine its impact on state governance of economic security.

\section{1. Ветуп}

Забезпечення воєнної безпеки - це одне з найважливіших завдань, яке стоїть перед державою і є складовою національної безпеки. Для виконання даного завдання здійснюються складні політичні, економічні, військові та інші заходи. Головна роль належить політичним заходам, які спрямовані на формування сприятливих умов для функ-

\footnotetext{
${ }^{1} \mathrm{PhD}$ in Public Administration, Postdoctoral Student, National Academy of Public Administration under the President of Ukraine, Ukraine

(C) Hbur Zoriana
} 


\section{Hbur Zoriana}

ціонування суспільства всередині країни та поза ії межами, особлива увага приділяється зміцненню міжнародного визнання держави та недопущення поточних та можливих конфліктів. Важливо підкреслити, що будь-які заходи будуть ефективними лише у випадку сполучення їх з оборонними діями, що спрямовані на стримування можливих агресорів та блокування їх спроб порушити цілісність країни.

Дослідженню цього питання приділяли свою увагу ряд науковців та політичних діячів, серед них: Р. Арзуманян [1], О. Василенко [2], О. Галака [3], В. Горбулін [4; 5], А. Демидов [6], С. Магда [7], Мальський [8], В. Предборський [9], Л. Савин [10] та інші.

Метою цієї статті є розкриття сутності гібридної війни та визначення ïï впливу на державне управління економічною безпекою.

\section{2. Поняття та суть «гібридної війни» \\ у зарубіжній та вітчизняній літературі}

Специфіка збройних протистоянь, місце та значення військового аспекту у державному управлінні залежить від рівня економічного розвитку та технологічної складової. У процесі ускладнення воєнної зброї та техніки, який відбувається паралельно з вдосконаленням інших суспільних процесів та громадської свідомості, породжуються властиві даному розвитку методи воєнного протистояння.

Формальною війною вважається зіткнення збройних сил однієї держави зі збройними силами іншої. Таке зіткнення супроводжується формальним актом оголошення війни. Неформальні війни - це збройні конфлікти, в яких принаймні одна або обидві сторони є недержавними утвореннями. Нові загрози, що виникли після закінчення холодної війни, призвели до виникнення феномену сірої зони, тобто до комбінації війни і воєнних дій з організованою злочинністю (наприклад, конфлікту у Республіці Ічкерія). Формальні війни можуть набувати традиційної та нетрадиційної форм. Традиційні війни - це воєнні дії регулярних збройних сил однієї країни проти регулярних і нерегулярних збройних сил (партизанські війни) іншої країни із застосуванням звичайних засобів збройної боротьби. Традиційні війни - контактні, їх подальший розвиток пов'язаний з розробленням нових способів і засобів збройної боротьби. У поєднанні $з$ новітніми інформаційними технологіями вони породжують такі форми, як мережеві та мережо-центричні війни [2, с. 20-22]. 


\section{Hybrid war and its impact on economic security government}

Нетрадиційні війни - це зіткнення регулярних збройних сил країни з іррегулярними формуваннями, угрупованнями, загонами, які не визнають норм і правил ведення воєнних дій. Формальні та неформальні воєнні конфлікти можуть бути симетричними й асиметричними.

Асиметричний конфлікт відбувається за участю суб'єктів, що якісно відрізняються стосовно силового потенціалу й принципів організації та управління. Навіть без переходу до воєнної фази асиметричний конфлікт має ряд специфічних ознак, які є наслідком обмеженого арсеналу засобів для слабших учасників. В асиметричних відносинах сильний партнер зазвичай не потребує застосування додаткових силових заходів для нав'язування власної волі. Тому конфлікт часто відбувається в латентному вигляді, лише епізодично переходячи в збройну фазу у формі жорстоких і на перший погляд ірраціональних дій, зокрема терористичних актів. Такі дії є тим засобом з обмеженого арсеналу, за допомогою якого слабший партнер впливає (і потенційно перемагає) на сильнішого [3, с. 24-26].

У сучасних умовах формується новий вид загрози державній цілісності під назвою «гібридна війна». Для більш глибокого розуміння іiі впливу на державне управління економічною безпекою слід розглянути основні підходи до визначення даного поняття.

Автором цієї концепції є Френк Г. Хоффман, колишній офіцер морської піхоти, науковий співробітник міністерства оборони США. Це великий теоретик в галузі збройних конфліктів та військово-політичної стратегії. Автор зазначає, що конфлікти будуть мультимодальними (тобто такими, що ведуться різними способами) та багатоваріантними, що не входять в межі простої конструкції ведення збройного конфлікту чи війни. За Г. Хоффманом майбутні загрози можуть в більшій мірі бути охарактеризованими як гібридне співвідношення традиційних та нерегулярних стратегій і тактик, це децентралізоване планування та виконання, участь недержавних акторів з використанням одночасно простих та складних технологій [11].

Сьогодні ж існують різні варіанти визначення сутності гібридної війни [1, с. 22-39]:

1) військова стратегія, яка поєднує звичайну війну, малу війну та кібервійну;

2) атака з використанням ядерної, біологічної, хімічної зброї, саморобних знарядь для терористичних атак та інформаційного тиску; 


\section{Hbur Zoriana}

3) складна та гнучка динаміка бойового простору (battlespace), яка передбачає швидку реакцію та адаптацію учасників протистояння;

4) сучасний вид партизанської війни, яка поєднує сучасні технології та методи мобілізації (Біл Неметт, підполковник Корпусу морської піхоти США);

5) основний метод у асиметричній війні, яка ведеться на трьох умовних фронтах - серед населення конфліктної зони, тилового населення та міжнародної спільноти (полковник Армії США Джек МакКуен);

6) Франк Хоффман визначає гібридну війну у вигляді будь-яких дій ворога, який швидко та гнучко використовує найрізноманітніші комбінації дозволеної зброї, партизанську війну, тероризм, злочини на полі бою, і все для досягнення політичних цілей.

У свою чергу Є. Магда [7] зауважує, що гібридну війну можна у найзагальніших рисах визначити як сукупність заздалегідь підготовлених і оперативно реалізованих дій військового, дипломатичного, економічного, інформаційного характеру, спрямованих на досягнення стратегічних цілей. До складових гібридної війни відносяться традиційні та нестандартні загрози, тероризм, підривні дії, коли використовуються новітні чи нешаблонні технології для протидії перевазі супротивника у військовій силі.

Науковець М. Айшервуд пропонує наступне трактування «гібридної війни» - це війна, що стирає різницю між чисто конвенційною та типово нерегулярною війною [10].

Проаналізувавші деякі підходи та визначення різних науковців та державних діячів, можемо запропонувати власне визначення. Отже, гібридна війна - сукупність засобів та інструментів, які використовуються противником, до складу яких входить не тільки і не стільки ядерна, біологічна, хімічна зброя, а комплекс інформаційних, високотехнологічних, кібернетичних засобів впливу, психологічний тиск 3 метою досягнення політичних цілей.

На переконання В. Передборського, гібридна війна 3 визначним синергетичним ефектом є проявом визначає синкретизму, змішування, які мають такі основні форми [9]:

- форми організації сил, використання засобів війни - за критерієм масштабу використання збройних сил - використання великомасштабних та невеликих, мобільних підрозділів 3 високотехнологічною зброєю, системами зв'язку, інформаційною технікою; 
- форми організації сил - за критерієм відношення до офіційної влади - державних та парамілітарних (партизанських), добровольчих підрозділів збройних сил. Україні (як і Росіі) завжди було характерним широке застосування, окрім державних військових формувань, партизанських, добровольчих, інших парамілітарних підрозділів. За сучасних умов значення невеликих мобільних військових угрупувань, у тому числі альтернативних до держави, з функцією виконання диверсійно-розвідувальних, штурмових, терористичних, інших спеціальних завдань різко зростає;

- принципово змінюється значення синкретичних засобів (функцій) колишнього забезпечення основної ударної функції військ - відбувається синергетичне посилення, застосування кібернетичних, пропагандистських, медійних, інформаційних, психологічних, космічних засобів, переведення їх у сегмент основних функцій війни;

- посилення синергетично-синкретичних засобів ведення війни засобами іiі ресурсного забезпечення - дипломатичного, економічного, торгівельного, фінансового, корупційного, енергетичного тощо; синхронізація їх застосування у складі інших засобів військової політики щодо інших основних засобів війни.

У таких конфліктах противники (держави; групи, що фінансуються державами, або суб'єкти, які самі фінансують свою діяльність) будуть мати доступ до сучасного воєнного потенціалу, що включає зашифровані командні системи, переносні ракети класу «земля-повітря» та інші сучасні смертоносні системи; а також - підтримувати організації затяжних партизанських дій, в яких застосовуються засідки, саморобні вибухові пристрої та вбивства [11].

Коли справа дійде до політичних цілей, гібридні війни, скоріш за все, матимуть вигляд нерегулярної війни, де ії учасники робитимуть спроби та намагатимуться підірвати легітимність та авторитет керуючого режиму. Це вимагатиме від збройних сил держави допомоги, щоб закріпити здатність держави забезпечувати соціальні, економічні та політичні потреби свого народу [11].

У цьому контексті М. Айшервуд також зазначає, що потенційно гібридну війну сьогодні можуть вести багато конфліктуючих держав. Він пояснює, що складний характер гібридної війни вимагає від воєначальників та цивільних лідерів розуміння свого операційного оточення або відчуття бойового простору. Гібридний противник може 


\section{Hbur Zoriana}

приховуватися поміж цивільного населення, бути не схожим на типового ворога та використовувати «електронний притулок», створений глобальним телекомунікаційним ринком [10].

Відмінність гібридної війни полягає у тому, що противним замається декількома фазами воєнних дій одночасно і тим самим потребує зовсім інші вимоги до реакції збройних сил. А. Демидов [6] також поділяє цю думку.

На думку В. П. Горбуліна, кожен конкретний елемент «гібридної війни» не новий по суті й використовувався майже в усіх війнах минулого, але унікальними є узгодженість і взаємозв'язок цих елементів, динамічність та гнучкість їх застосування, а також зростання ваги інформаційного чинника. Причому інформаційний чинник в окремих випадках стає самостійним складником і виявляється не менш важливим, ніж військовий [4].

3 огляду на це Л. Савин пропонує класифікацію видів зброї, яка використовуються у таких умовах [10]:

1.Модельно організаційна - зброя, що грунтується на особових базах даних політиків, державних службовців, бізнесменів, псевдо- та ксеноліти країни противника. Ці бази збирають за допомогою різних міжнародних організацій, благодійних фондів, радників, політологів та інших підготовлених служб. У цих базах даних міститься інформація про рахунки з-за кордону, а також компрометуюча інформація. Основні бази даних використовуються для залякування і розкладання політичної та державної еліти для формування кола підтримки та запобіганню супротиву.

2. Інформаційна зброя має таку класифікацію за ознаками:

- за якістю інформації;

- за носієм інформації;

За якістю інформаційна зброя класифікується:

- концептуальна-методологічна - це формування глобальної політики, що спрямовується на різні народи з метою створення якогось конкретного спланованого виміру розвитку історичних подій.

- хронологічна зброя - інформація хронологічного плану - є послідовність фактів на явищ. дає можливість розглядати всі явища історичного процесу та прогнозувати вектори майбутньої політики.

- факторологічна зброя - це ідеологія, релігія, технології. саме ці види зброї дають можливість підпорядкувати собі противника 


\section{Hybrid war and its impact on economic security government}

3. Матеріальна зброя поділяється на:

- економічну зброю - включає засоби економічної боротьби 3 дезорганізацією структур противника і подальше їх поглинання. Сюди входить контроль фінансово-кредитної системи країни та контрольна іншими економічними системами держави, борговими зобов'язаннями розподілом коштів, повернення фінансів в державу, прибутковість державного сектору в економіці, іiі частка.

- зброю геноциду - включає етнічний геноцид, наркотичний, алкогольний, інформаційно-економічний та інший;

- звичайна зброя фізичного знищення.

Як підкреслює В. Гобулін, що нинішня безпекова криза вирізняється тим, що розгортається за умов глобалізації, тобто кардинального підвищення ступеня взаємної залежності суб'єктів міжнародної політики, а це вимагає підвищення рівня відповідальності учасників системи міжнародних відносин. Нехтування міжнародними зобов'язаннями, зокрема 3 боку впливових світових держав та їх об'єднань, призводить до небезпечних наслідків на регіональному та глобальному рівнях $[5$, с. 46$]$.

Головною загрозою економічній безпеці України є агресія з боку Російської Федерації, яка змушує українців приймати рішення про обрання колективної системи безпеки через Організацію Північноатлантичного договору (НАТО) та Європейський Союз, наслідуючи досвід більшості країн пострадянського режиму.

Влучною є думка М. Мальського, який стверджує, що вона «... підірвала ідею побудови системи загальноєвропейської безпеки, а також звела нанівець одне з головних досягнень, покладене у фундамент ОБСЄ, - Гельсінський заключний акт, в якому задекларовано такі міжнародні принципи, як повага до суверенітету, відмова від використання сили або погрози силою, визнання непорушності кордонів та територіальної цілісності держав, мирне врегулювання суперечностей, невтручання у внутрішні справи, повага до прав і свобод людини, рівноправ'я країн та право народів розпоряджатися власною долею, співробітництво між державами, дотримання зобов'язань згідно з міжнародним правом» [8, с. 45].

Сучасні умови міжнародного середовища характеризуються процесам и глобалізації, розвитком економіки та міжнародних норм права, зростанням рівня науково-технічного прогресу та інноваційних техно- 


\section{Hbur Zoriana}

логій. Однак на заваді загальносвітовому благополуччю постало нове явище «гібридна війна». Сутність проблеми полягає у розкритті сутності даного поняття у контексті сучасних реалій ведення війни, що відбувається поза межами, що окреслені у конвекційно-закріплених стандартах та правилах. Дослідження даного питання є актуальним у зв'язку з тим, що проблема «гібридної війни» піднімається не лише у наукових колах, а й на різних рівнях державного управління, юридичних структур з метою забезпечення безпечних умов функціонування всіх сфер державного функціонування.

Сучасний стан розвитку світового господарства характеризується розповсюдженням різнопланових форм гібридних війн. Дана ідея не $є$ новою, оскільки у військовій історії існує немало прикладів нетрадиційних війн, в яких використовувалася нелінійна тактика та нерегулярні збройні формування, які є прадавніми формами даного виду протистояння.

Зазвичай гібридні форми війни не є суто воєнним протистоянням, а включають економічні, психологічні та партизанські засоби нападу. Структура та величина впливу цих компонентів, міра їх використання у певному протистоянні залежать від поточного рівня розвитку економіки та технологій.

Загальновідомо, що війни та збройні конфлікти $є$ просторово-часовими процесами, в основі яких лежать найрізноманітніші суперечності, а також використання різномасштабних військових формувань на певних територіях для досягнення певних цілей. Гібридні сили успішно використовують технологічно передові системи таким чином, що вони працюють на межі можливостей. Тому гібридні збройні сили мають перевагу над традиційною армією, яка діє суворо в рамках уставу. Загалом, гібридна загроза відзначається тим, що стирає традиційні уявлення та практики війни [2].

Як зауважує В. Предборський, необхідність модернізації вітчизняного суспільства часто обмежується копіюванням досвіду вестернізації, чи удосконаленням радянської моделі реформування, що призводить лише до зростання численних загроз національній безпеці, серед яких одне з головних місць належить феномену синергетичної системи управлінських криз, активованих як зовнішніми, так і внутрішніми чинниками. Процеси кризового інвазійного тиску захопили не тільки соціально-економічні, а й інші суспільні процеси, зокрема 


\section{Hybrid war and its impact on economic security government}

військові, перетворивши їх на систему модифікованого кризового механізму функціонування суспільства. У зв'язку з цим реформування у будь-якій сфері життя і діяльності (політичній, соціальній, економічній, військовій, організаційній, правовій) у сучасному вітчизняному суспільстві має спиратися на загальні закономірності адекватного реформування [5].

Існує загалом два підходи до розуміння сутності війни. Перший, пов'язаний з традицією Карла фон Клаузевіца, визначає війну як організоване насильство, що має на меті досягнення соціальних та політичних цілей. Цей підхід дистанціюється від моральних, правових, етичних аспектів війни, або сприймає їх через призму військово-політичних інтересів. Другий підхід виходить із праць Цицерона, який твердив, що війна - це правова ситуація та умови, яке легітимізують насильство та визначають його допустимі межі. Таким чином вводиться поняття «мирний стан» та «військовий стан», залежно від того чи $€$ насильство легітимним. Розрізнення мирного та військового стану $\epsilon$ критично необхідною річчю. Війна створює принципово іншу реальність, формує власне розуміння моральної, етичної, правової норми, яке потребує визначення засобами військового права. Поки правове поле залишається невизначеним, ми не можемо говорити про організоване ведення бойових дій, а насилля може стати неконтрольованим, що тим не менш, не означатиме війни [1, с. 39].

Відповідно, саме ці особливості і є основною загрозою гібридної війни. В умовах війни зазвичай складно чітко визначити, хто $є$ суперником у конкретному протистоянні, а також визначити джерело впливу правових, етичних та моральних фреймів.

\section{3. Актуальні гібридні загрози економічній безпеці України та досвід протидії гібридним загрозам в Польщі}

Незважаючи на вже триваючу четвертий рік гібридну війну Росії проти України, низка гібридних загроз з 2014 року залишаються актуальними і на сьогодні, створюючи небезпеку дестабілізації й ослаблення нашої держави, порушення фундаментальних прав і свобод, зниження рівня життя та власне і самого мирного існування громадян України.

Для ідентифікації гібридних загроз слід розмежувати поняття «виклик», «ризик», «небезпека», «загроза», «надзвичайна ситуація», 


\section{Hbur Zoriana}

які є базовими в теорії «безпеки». Часто деякі з них ототожнюються і вживаються як синоніми, що не завжди відповідає реальному стану речей.

У цьому контексті варто навести визначення поняття «гібридна загроза» - це будь-який противник, який одночасно та адаптовано використовує співвідношення звичайного озброєння, нерегулярну тактику, тероризм та злочинну поведінку в зоні бойових дій для досягнення своїх політичних цілей [9].

Гібридні загрози включають в себе коло різних режимів ведення війни, що відносить до себе стандартне озброєння, нерегулярні тактики і формування, терористичні акти (в тому числі і насилля та примус) і кримінальний безлад. На сьогоднішній час цей термін має три гілки. Гібридність може відноситися, перш за все, до військової ситуації та умовам; по-друге, до стратегії та тактики противника; по-третє, до типу сил, які держава повинна створювати та підтримувати [9].

Розмірковуючи про виникнення воєнних загроз, слід визначити основні джерела і чинники воєнної небезпеки України в сучасних умовах. Як зауважує I. Руснак, існуючі джерела воєнної небезпеки для України за походженням можна поділити на зовнішні та внутрішні. До основних зовнішніх джерел належать [6]:

- наявність територіальних претензій до України;

- зацікавленість у зміні зовнішнього та внутрішнього політичного курсу України на свою користь;

- прагнення до зменшення політичної, економічної, воєнної ваги України в інтересах свого домінування в регіоні;

- ведення проти нашої держави ворожої пропаганди, підтримка дій сепаратистських сил в Україні, сприяння розпалюванню міжетнічних та міжконфесійних протиріч;

- зацікавленість у встановленні контролю над стратегічними об'єктами та комунікаціями України;

- наявність поблизу кордонів України значних угруповань військ.

Актуальність наведених джерел набувають особливого значення 3 огляду на інші об'єктивні чинники, які походять із сусідніх держав. До таких чинників можна віднести [6]:

- внутрішня економічна й соціально-політична нестабільність;

- недостатня правова врегульованість міждержавних відносин 3 Україною. 
- наявність потужного воєнного потенціалу в поєднанні з перманентним зростанням воєнних витрат.

Характер сучасних та майбутніх війн визначається тенденціями розвитку форм та способів ведення збройної боротьби. Серед них варто відзначити [2]:

1.Зростання значення стратегічного неядерного стримування супротивника шляхом масового оснащення військ новітніми засобами збройної боротьби для ведення неядерних, неконтактних (дистанційних) бойових дій;

2.Підвищення ролі динамічності та маневреності в діях військ на розрізнених напрямках з широким застосуванням сил швидкого реагування, аеромобільних військ і військ спеціального призначення;

3. Розширення простору та масштабів збройної боротьби, перенесення бойових дій із землі і поверхні морів у повітря, під воду та у космос. Одночасне вогневе та електронне ураження військ, об'єктів тилу, економіки, комунікацій на всій території супротивника;

4.Зростання ролі протиборства в інформаційній сфері та використання новітніх інформаційних технологій;

5.Боротьба 3 міжнародним тероризмом, створення експедиційних сил для проведення миротворчих і антитерористичних операцій.

Що стосується міжнародного досвіду, то в СС доволі чітко ідентифікували «гібридні загрози» та визначали заходи протидії. Була розроблена низка документів, включаючи Глобальну стратегію $\mathrm{EC}$, Спільний рамковий документ 3 протидії гібридним загрозам (06.04.2016 р.) [7] і Спільна доповідь Свропейському парламенту і Європейській Раді з його імплементації (19.07.2017р.) [8], Оперативний протокол $\mathrm{EC} 3$ протидії гібридним загрозам "EU Playbook" (05.07.2016 р.), Спільний робочий документ «Східне партнерство 20 очікуваних досягнень до 2020 року: фокусуючись на головних пріоритетах та реальних результатах» (15.12.2016 р.), доповідь Свропейського парламенту «Протидія гібридним загрозам: Співпраця ЄС-НАТО» (березень 2017 р.)

В СС класифікують сфери протидії таким загрозам: інформаційна сфера, енергетика, транспорт та інфраструктура, космос, військова сфера, охорона здоров'я і продовольча безпека, кібер-простір, фінансова сфера, промисловість, громадський або суспільний вимір. Слід зазначити, що в ЄС досить серйозно підійшли до виявлення гібрид- 


\section{Hbur Zoriana}

них загроз і ще минулого року запропонували створити Центр аналізу гібридних загроз ЄC (EU Hybrid Fusion Cell) в рамках Розвідувального і ситуативного центру СС (EU Intelligence and Situation Centre, EU INTCEN) Свропейської служби зовнішньої дії. Саме на цю нову структуру, яка у травні 2017 року набула повної оперативної здатності, і покладається завдання збору, аналізу і доведення відкритої та закритої інформації стосовно індикаторів та попереджень про гібридні загрози. Цей Центр підводить гібридні загрози під єдиний європейський знаменник та доводить відомості про них, у тому числі й у формі «Гібридного Бюлетеня» (Hybrid Bulletin), до інституцій ЄС і країн-членів Свросоюзу [4].

В Україні ж під загрозою виявились практично усі сфери суспільного життя - економіка, політика, культура пам'яті та інформаційного споживання, навіть ідентичність. Слабка диверсифікація ринків збуту української продукції, прив'язаність до російського ринку базових секторів вітчизняного господарства, відсутність альтернативних джерел постачання ресурсів - усе це перетворилося на питання національної безпеки. Промисловість, інфраструктура залишаються енерговитратними й малоефективними. Відсутність адекватної інформаційної та культурної політики спричинила культурну окупацію свідомості значної частини громадян. Зусиллями пропаганди була нав'язана штучна проблема дискримінації російськомовного населення, страх перед ефемерною загрозою «бандерівщини». Український інформаційний простір без належного російськомовного й англомовного контенту виявився замкненим, неконкурентним, не готовим донести українську позицію до світової спільноти [2].

Дослідник В. Мартинюк пропонує наступну класифікацію гібридних загроз економічній безпеці Україні та суспільству на сучасному етапі [4]:

1) у військовій сфері:

- діяльність незаконних збройних формувань на території України, що спрямована на дестабілізацію внутрішньої соціально-політичної ситуації в Україні, порушення функціонування органів державної влади, органів місцевого самоврядування та блокування важливих об'єктів промисловості й інфраструктури;

- діяльність диверсійно-розвідувальних груп агресора під маскою українських силовиків з метою дискредитації останніх; 
- нелегальне розповсюдження (торгівля) зброєю, що призводить до неконтрольованого володіння зброєю населенням країни та можливостей іï придбання;

- цілеспрямовані заходи дискредитації збройних сил України та інших військових формувань і силових структур;

2) у правоохоронній сфері:

- використання компромату на представників правоохоронної системи не для усунення їх від роботи, а для просування необхідних для зацікавленої сторони рішень;

- фізичне усунення активно діючих співробітників правоохоронних органів;

- використання зовнішнього впливу на злочинні елементи для розхитування ситуації в Україні;

3) в інформаційній сфері:

- відкрите і приховане використання демократичних норм та процедур країн $С С$, а також США й інших країн-партнерів для інформаційної дискредитації України та іiї спроб формувати міжнародну підтримку протидії російській агресії;

- політичні та лобістські заходи на Заході, які використовуються Росією для формування сумніву у правильності позиції країн ЄС щодо продовження санкційного впливу на Кремль, а також для легітимації анексії Криму;

- використання українських телевізійних каналів та інших медіа для трансляції проросійських наративів у дозованому вигляді чи під опозиційними гаслами;

- поширення інформаційних продуктів з використанням регіональної, етнонаціональної, мовної та іншої партикулярної ідентичності серед громадян України для формування ліній розколу в суспільстві, нав'язування відчуття дискримінації та незахищеності, підготовки соціальної бази для протестів та провокацій;

4) у кібер-сфері:

- збереження присутності російських банків в Україні, які продовжують контролювати значну частину фінансів бізнесу і громадян;

- контроль над важливими економічними активами в Україні, зокрема в енергетичному секторі (обленерго, облгаз), з боку російських або проросійськи налаштованих власників, що робить можливим тихі диверсії (саботаж, умовні аварії і простої), впровадження 


\section{Hbur Zoriana}

шкідливого програмного забезпечення для подальших кібер-атак, руйнування стратегічних підприємств;

- зовнішній економічний вплив на діяльність крупних підприємств, що створює передумови для впливу на великі робітничі колективи та маніпулювання (шахтарські протести);

5) у сфері прав людини, національних меншин:

- експлуатація зовнішнім суб'єктом тематики «захисту прав національних меншин», «порушення прав в сфері мовної політики», «прояву дискримінації за національною ознакою» задля досягнення власних цілей;

- використання питань мовної політики для дестабілізації ситуації в крані;

- інспіровані ззовні ущемлення прав національних меншин з метою розпалювання міжетнічної ворожнечі, стимулювання проявів сепаратизму і дестабілізації ситуації тощо.

Як наголошують аналітики, гібридні загрози також концентруються у невійськовій сфері. До основних транснаціональних загроз для України, що активно експлуатуються у гібридній війні, на сучасному етапі можна віднести [3]:

- наявність сепаратистських тенденцій в окремих прикордонних районах: на додачу до тимчасово окупованих Криму та частини території Донбасу спостерігаємо непевність на Закарпатті (русинський сепаратизм); наявність подвійних паспортів у мешканців Буковини, Закарпаття, прикордонних територій з Московською Федерацією, що дають змогу використовувати карту «захисту своїх громадян»;

- відсутність ефективних механізмів забезпечення законності, правопорядку, боротьби зі злочинністю, особливо ії організованими формами і тероризмом; як результат маємо неконтрольоване проникнення диверсійних груп та груп провокаторів на територію України;

- неконтрольований відплив за межі України матеріальних і фінансових ресурсів, передусім із непідконтрольних територій;

- безпідставна міграція (коли мешканці непідконтрольних територій приїжджають в Україну за пенсіями та виплатами і повертаючись назад підтримують окупацію України Москвою) та криміналізація суспільства.

Така різноманітність слабких місць у контексті гібридних загроз дозволяє зробити висновок про те, що дане питання залишається акту- 


\section{Hybrid war and its impact on economic security government}

альним і сьогодні, що в свою чергу створює небезпеку дестабілізаційних процесів та ослаблення України шляхом порушення системи прав і свобод громадян, зниження рівня їхнього життя та мирного існування.

Таким чином, ми бачимо, що в умовах «гібридної» війни на передній план виходять проблеми насильницького розв'язання конфліктів, що характеризується високою інтенсивністю і широким застосуванням методів прямої агресії, а також здатністю залучати у свою сферу і заражати все нових людей, руйнуючи історично сформовану систему державної стабільності i, отже, безпеку. Що б перемогти у «гібридній» війні треба мати найсучасніші збройні сили, силові структури, що здатні до проведення антитерористичної боротьби, удосконалені та захищені засобі інформаційної боротьби.

Тематика війни гібридного типу стала опрацьовуватись в Польщі після доволі швидкого усвідомлення того, що чинить Росія проти України, починаючи з 2014 року. Спочатку польська стривоженість була обумовлена неясністю подальших намірів Росії в Європі та агресивних дій проти Польщі, сусідніх країн Балтії, а також НАТО та СС, які РФ ідентифікує як не дружні до неї західні альянси. 3 часом в Польщі дійшли висновку, що потенційні гібридна агресія Росії проти Польщі за українським зразком малоймовірна. Польське суспільство досить монолітне. Основну ставку в протидії гібридним загрозам Польща робить на багатосторонню взаємодію в рамках НАТО та ЄС. Варшава також проводить активно лінію співпраці обох альянсів за для їх взаємного посилення за принципом «у двох краще ніж самому».

\section{4. Методологія дослідження}

Методологічну основу статті становлять загальнонаукові прийоми дослідження і методи, що грунтуються на сучасних наукових засадах управлінської, юридичної і споріднених із ними наук.

У роботі використано такі методи:

- системний підхід - для дослідження і формулювання поняття гібридна війна, гібридні загрози та вплив на економічну безпеку України;

- метод аналізу і синтезу - для аналізу та опису динаміки загроз в різних регіонах нашої країни у 2016-2017 рр.;

- логічний метод - для дослідження еволюції постановки проблеми й наступності іï вирішення, для встановлення зв'язків між суспільними явищами та подіями. 


\section{Hbur Zoriana}

\section{5. Пошуки}

На сьогоднішній день приймаються рішення щодо долі України в Європі, тому наша держава повинна не тільки сформувати безпечне середовище, а й зробити внесок у колективну безпеку Європи. Загальновідомо, що євро інтеграційні процеси та налагодження євроатлантичної співпраці пов'язане з безліччю ризиків. Тому обраний курс України на європейську інтеграцію, яка є невід'ємною складовою євроатлантичного простору, зумовлює необхідність розвитку нових суспільно-політичних моделей держави, розробки відповідних стратегій розвитку економічної системи України, а особливо, військово-промислової складової.

Отже, об'єктивні закономірності вітчизняних суспільних процесів, їх модернізації призводять до значного поширення та піднесення ролі синкретичних, нероздільних, гібридних трендів, у тому числі у військовій справі. Використання гібридних суспільних форм, гібридних засобів війни здатне забезпечити дифузійне врощення цих інструментів у процеси модернізації, принципово підсиливши свій вирішальний вплив на іï якість, зробити їх у певній мірі захищеними, непомітними для дії традиційних небезпек їх функціонуванню, військових засобів виявлення, ідентифікації та протидії, забезпечує появу нової якості використання гібридних форм як інституційної матриці з якісно новими можливостями - своєрідних соціальних технологій «стелс», яку нездатна уразити традиційна зброя інституційного, соціального та військового призначення.

\section{6. Висновки з дослідження}

Практично весь час, починаючи 31991 року, Україна не приділяла належної уваги зміцненню власної безпеки, вважаючи що їі оточення $\epsilon$ потенційно дружнім і не несе серйозних загроз безпеці держави i суспільства. Рік у рік система безпеки України послаблювалась, що виражалось не лише в нездатності Збройних Сил виконувати свої завдання за призначенням, але й ослабленні державної системи вцілому та іiї окремих безпекових компонентів зокрема економічної безпеки.

Як висновок з усього викладеного вище варто узагальнено зазначити гібридні загрози економічній та національній безпеці України які залишаються актуальними і сьогодні. 
На національному, загальнодержавному рівні:

- політична війна в українському середовищі правлячої політичної групи, що стимулюється ззовні агресором через внутрішньо-українську агентуру впливу;

- неефективність парламенту, що не відповідає визначеній Конституцією України парламентсько-президентській моделі;

- незадовільний професійний рівень державної служби України;

- PR-активність влади замість предметної діяльності;

- корупційна діяльність у всіх секторах економіки і навіть в тих які покликані упереджувати та боротись з корупцією;

- комбіновані дії комплексного характеру з метою нарощування протестного потенціалу суспільства проти неефективної влади;

- використання українських телевізійних каналів та інших медіа для трансляції проросійських наративів у дозованому вигляді чи під опозиційними гаслами.

В економічній сфері:

- збереження присутності російських банків в Україні, які продовжують контролювати значну частину фінансів бізнесу і громадян;

- контроль над важливими економічними активами в Україні;

- впровадження на підприємствах державного значення програмного забезпечення для подальших кібер-атак;

- руйнування стратегічних підприємств;

- зовнішній економічний вплив на діяльність крупних підприємств.

\section{Список літератури:}

1. Арзуманян Р.В. Определение войны в 21 веке. Обзор XXI ежегодной конференции по стратегии Института стратегических исследований Армейского военного колледжа, 6-8 апреля 2010 / Р.В. Арзумян. - Ереван, 2011. -60 c.

2. Василенко О.В. Основні світові тенденції розвитку озброєння та військової техніки для ведення війн у майбутньому / О.В. Василенко // Наука і оборона. - 2009. - № 4. - С. 18-22.

3. Галака О. М., Ільяшов О. А., Павлюк Ю. М. Основні тенденції розвитку та ймовірні форми воєн і збройних конфліктів майбутнього / О. М. Галака, О. А. Ільяшов, Ю. М. Павлюк // Наука і оборона. - 2007. - № 4. - С. 10-15.

4. Горбулін В. П. «Гібридна війна» як ключовий інструмент російської геостратегії реваншу / В. П. Горбулін // Стратегічні пріоритети. - 2014. № 4. - C. 5 . 


\section{Hbur Zoriana}

5. Горбулін В.П. Донбас і Крим: ціна повернення: монографія / за заг. ред. В.П. Горбуліна, О.С. Власюка, Є.М. Лібанової, О.М. Ляшенко. - К.: НІС, $2015-474$ c.

6. Демидов А.В. Управляемый хаос. Стратегия Росии № 5, май 2015 - Електронний ресурс / Режим доступу: http://sr.fondedin.ru/new/ fullnews.php? subaction=showfull \&id=1430428108\&archive $=1430773984 \&$ st art from $=\& u c a t=14 \&$

7. Магда Є.М. Гібридна війна: сутність і структура феномену / Є. Магда // Міжнародні відносини: Серія «Політичні науки». - 2014. - № 4.

8. Мальський М.3. Транскордонна безпека: політико-правовий, соціально- економічний, гуманітарний та екологічний вимір. Збірник матеріалів Міжнародної науково-практичної конференції, Львів, 21 квітня 2017 року / Упорядники: М. 3. Мальський, О. С. Кучик, Р. В. Вовк. - Львів: Факультет міжнародних відносин, 2017. - 96 с.

9. Предборський В. А. «Гібридна» війна як відбиття закономірностей розвитку суспільства незавершеної модернізації / В. А. Предборський // Формування ринкових відносин в Україні. - 2014. - № 10. - С. 13-18.

10. Савин Л. Гибридная война. / Информационно-аналитический портал Геополитика. 27янв. 2015 - Електронний ресурс / Режим доступу: http:// geopolitica.ru/article/gibridnaya-voyna\#.VazC1qTtmko

11. Major Shane R. Reeves, Major Robert E. Barnsby The New Griffin of War. Hybrid International Armed Conflicts // Academic joutnal article "Harvard International Review" 2013. - Електронний ресурс / Режим доступу: https:// www.questia.com/library/journal/1G1-316203914/the-new-griffin-of-war-hybridinternational-armed

\section{References:}

1. Arzumanian R.V. (2011), Opredelenye vojny v 21 veke. Obzor XXI ezhehodnoj konferentsyy po stratehyy Ynstytuta stratehycheskykh yssledovanyj Armejskoho voennoho kolledzha [The definition of war in the 21 st century], Yerevan, Armenia.

2. Vasylenko O.V. (2009), "The main world trends in the development of weapons and military equipment for future wars", Nauka i oborona, no. 4, pp. $18-22$.

3. Halaka O. M., Il'iachov O. A., Pavliuk Iu. M. (2007), "The main trends of development and probable forms of wars and armed conflicts of the future", Nauka i oborona, no. 4, pp. 10-15.

4. Horbulin V. P. (2014), "Hybrid War; as a key tool of Russian geostrategy of revenge", Stratehichni priorytety, no. 4, pp. 5.

5. Horbulin V. P. (2015), Donbas i Krym: tsina povernennia: [Donbass and Crimea: returning price], NIS, Kyiv, Ukraine.

6. Demydov A.V. (2015), "Controlled chaos", Stratehyia Rosyy, no. 5, available at: http://sr.fondedin.ru/new/fullnews.php?subaction=showfull\&id= $1430428108 \&$ archive $=1430773984 \&$ start from $=$ \&ucat $=14 \&$.

7. Mahda Ie. M. (2014), "Hybrid war: the essence and structure of the phenomenon", Mizhnarodni vidnosyny, no. 4. 
8. Mal's'kyj M.Z. (2017), "Cross-border security: political, legal, socioeconomic, humanitarian and environmental dimensions.", Zbirnyk materialiv Mizhnarodnoi naukovo-praktychnoi konferentsii, $96 \mathrm{p}$.

9. Predbors'kyj V. A. (2014), "Hybrid war as a reflection of the laws of development of a society of incomplete modernization", Formuvannia rynkovykh vidnosyn v Ukraini, no. 10, pp. 13-18.

10. Savyn L. (2015), "Hybrid war", Informatsyonno-analytycheskyj portal Heopolytyka, available at: http:// geopolitica.ru/article/gibridnaya-voyna\#.VazC1 qTtmko.

11. Major Shane R. Reeves, Major Robert E. Barnsby (2015) "The New Griffin of War. Hybrid International Armed Conflicts, Academic joutnal article "Harvard International Review", available at: https://www.questia.com/library/ journal/1G1-316203914/the-new-griffin-of-war-hybrid-international-armed. 